\title{
2. The European Union policy framework for social services: agendas, regulations and discourses
}

\section{José Luis Gómez-Barroso, Stefania Barillà and Ivan Harsløf*}

\section{INTRODUCTION}

This chapter aims at assessing the EU's emergent policy framework - the agendas, regulations and discourses - concerning social services within the larger field of social protection. As discussed in Chapter 1, social services stand out as a contested and changing policy area in discussions about the architecture of the welfare state. Some countries adhere to a liberal welfare model where public social service provision is considered a paternalistic market interference. In others of more conservative orientation, it is feared as a potential threat to the social fabric of the family and local community. And even in countries with traditions of comprehensive and service-intensive welfare provisions, current debates revolve around the most appropriate level of government responsibility, mostly favouring decentralised social services designed and delivered by local authorities. These deep-seated differences in views and traditions complicate any supra-national regulation, and indeed, the European Union (EU), encompassing representatives of several different welfare models, has taken a somewhat ambivalent stance on the role of social services in a more integrated Europe.

This has been one of the reasons why, for half a century, social services were not explicitly included in the roadmap to an integrated European Union. The other main reason is that the European Economic Community was designed to create a level playing field to facilitate economic activity, and the social dimension was incorporated primarily to prevent unfair competition. Thus, although the European social charter signed in Turin by the member states of the Council of Europe on October 1961 established that 'everyone has the right to benefit from social welfare services' (Council of Europe, 1961, Article 14), the nearly contemporary Treaty of 
Rome made no reference to social services, and neither did the subsequent treaties. In 2012, the Charter of Fundamental Rights of the EU recovered an article incorporated in the 2004 failed project for a European constitution, recognising the entitlement to social services 'providing protection in cases such as maternity, illness, industrial accidents, dependency or old age, and in the case of loss of employment' as well as the 'right to social and housing assistance so as to ensure a decent existence for all those who lack sufficient resources' (Articles 34.1 and 34.3).

Regardless of the lack of references to social services in the Treaties, a number of non-binding forms of legislation were issued prior to 2000 on particular areas of social policy, together with - or as a result of - some valuable work behind the scenes that was done in agencies, observatories and networks. Since the early 2000s, a growing acknowledgment of social services occurred. It went hand in hand with the diffusion of the 'Social investment' approach sponsored by a number of scholars and think tanks in the late 1990s (Hemerijck, 2012). This approach considers social services not solely as a welfare 'right' for the individual, but also as a productive enterprise for society. At the same time, but not necessarily in tune with the above processes, a regulatory frame has been taking shape for social services, in the course of the implementation of the Single European Market. Over the past ten years, the content and specificities of the so-called 'social services of general interest' have been addressed by 'soft law' documents and rules have been established concerning the application of competition policy to public service providers and about the public funding of social services.

However, the growing acknowledgement of social services by the EU remains, as stressed earlier, ambivalent. After almost 60 years of work towards European integration, social services continue to be regarded mainly as a national affair. Indeed, the consolidated Treaty on the functioning of the EU clearly characterises the role of the Union as only complementary to national social policy (EC, 2012b, Article 153.1). This ambivalence notwithstanding, it is possible to refer to a European social policy framework that includes - albeit not always consistently - social services. To be more precise, it is possible to find a tangled set of policies with goals that are broadly related to social inclusion, by means also of the provision of social services, made of an even more tangled set of recommendations, actions, tools and budgets that have at least a potential impact on the local provision of social services.

In this chapter, the complex social policy framework and regulation established at the EU level is reviewed and critically assessed, with particular attention to its implications for social services. The review was carried out in the course of the COST Action IS1102 SO.S. COHESION-Social 
services, welfare states and places, to better understand the policy context of changes observed in the Action case studies. An account of the evolution of the EU general social policy agenda from 2000 to date (section 1) is followed by a review of the EU regulation of social services of general interest (section 2). Subsequently, the discourses and ideological tenets underlying the EU stance on social services are discussed (section 3), while some concluding remarks are made in section 4.

The main argument put forward is that, beyond the very ambitious discourses and goals set out in its documents, an ambivalent stance and a number of structural tensions permeate the EU social policy framework and especially the initiatives more specifically geared to social services. Among these tensions can be mentioned the gap between the very ambitious goals and the actual financial means; the tension between the attempt to set up a European regulatory framework and national sovereignty in the social domain; and the contradiction between competition policy applied to services and the right to welfare involved in social services. These unsolved tensions are the result of compromises between different approaches, goals and interests, which have yielded a very complex, often redundant set of guidelines, actions and funding schemes.

\section{THE EU SOCIAL POLICY STRATEGIES, FUNDS AND TOOLS IN THE NEW MILLENNIUM}

Arguably, the first formal commitment towards a more unified European social policy occurred in 2000 when, as a way of addressing the social dimension of the Lisbon strategy, the EU and its member states agreed on a European Social policy agenda, which was later integrated into the Europe 2020 strategy.

\section{The Lisbon Strategy and Europe 2020}

In what concerns social policy, three main phases can be identified in the Lisbon strategy (Agh, 2010).

The Lisbon I period (2000-2004) was set out in the European Council of Lisbon in 2000, featuring a very ambitious ten-year reform programme. The goal was to 'become the most competitive and dynamic knowledgebased economy, capable of sustainable economic growth with more and better jobs and greater social cohesion' (EC, 2000, p. 2). This involved among other things - 'modernising the European social model, investing in people and combating social exclusion' (EC, 2000, p. 5). This became the pillar of the 'new' European Social policy agenda and marked a shift from 
the previous sector-focused approach to a more integrated perspective (Decaro, 2011, p. 36). A key principle of the new agenda was the viewing of 'social policy as a productive factor' (EC, 2000, p. 5), in line with the 'social investment' approach sponsored by the EU in the late 1990s (Hemerijck, 2012). To implement the strategy, the European Council assumed a prominent coordinating role, introducing new governance tools: the 'Open method of coordination' as a means for spreading best practices without enforcing regulation; the annual 'Spring European Council' for monitoring progresses; and the 'Broad guidelines for economic policies'.

The Lisbon II period (2005-2008), which was set out in the mid-term review of the Spring council of 2005, inaugurated the 'renewed' Social policy agenda. Following the recommendations of the Kok report, the agenda was re-focused on growth and employment, while more responsibilities were given to member states. 'Integrated guidelines for growth and jobs' were adopted and a 'Community Lisbon programme' was drafted, which for the first time introduced regulatory measures, some financial instruments, and specific proposals for policy development, while, at the same time, member states had to prepare a 'National reform programme', adapting the Lisbon strategy to their national context.

The Lisbon III period (2008-2010) was launched at the Spring council of 2008 with only minor adjustments, focusing on implementation (Butković and Samardžija, 2010) and further stressing that social policy was crosscutting and multidimensional, covering a wide range of domains, from labour market policies to education, health, immigration and intercultural dialogue (EC, 2008a, p. 3). It also emphasised the need to connect the Lisbon strategy with the financial resources available for the European Cohesion policy, an important change in strategy that we shall address later in this section.

The Lisbon strategy and its Social policy agenda were re-examined at the end of the decade. As acknowledged in the document Europe 2020: A Strategy for European Union Growth (2010-2020), the EU faced intensified challenges, coming from further globalisation, climate change and demographic evolution, as well as from the aftershocks of the 2008 financial crisis. Its economic recovery needed to be supported by a number of reforms to guarantee a sustainable development in the coming decade (EC, 2014).

Europe 2020 explicitly placed social policy at the core of the EU new growth strategy (EC, 2013c), which was articulated in three priorities, five objectives (associated with precisely quantified 'headline targets'), and seven 'flagship initiatives'. Growth had to be 'smart', 'sustainable', but also 'inclusive'. The latter priority was articulated in two objectives 'Education' and 'Fight against poverty' - and two flagship initiatives - 
the 'Agenda for new skills and jobs' and the 'European platform against poverty and for social inclusion'. A number of monitoring and coordinating tools were also established (EC, 2013c): the 'European semester', a new institutional process providing member states with ex-ante guidance and the 'Annual growth survey', while the 'Open method of coordination' was reconfirmed for steering structural reforms.

Compared to the Lisbon strategy, the goals of Europe 2020 were more articulated and somewhat less high-sounding. Moreover, social inclusion now figured more prominently. The 'Social investment' approach was strengthened, as well as the tools to monitor and guide member states. On the other hand, although more cautious, goals remained rather ambitious (Lundvall and Lorenz, 2012, p. 334).

\section{The EU Policy Toolkit for Social Services in the Frame of Europe 2020}

With the launch of Europe 2020, all EU funds and programmes were now to comply with the new strategy. Of particular importance were the changes introduced in the European Structural and Investment Funds, the main financing tool of the European Cohesion policy. The two EC Directorates general (DGs) most directly involved in funding and implementing social policy were DG-EMPL (Employment, social affairs and inclusion) and DG-REGIO (Regional and urban policy).

$D G-E M P L$ is entrusted with all matters in the domains of employment, social affairs and social inclusion (EC, 2013d, p.4). More specifically it is responsible for: (1) social investment activities (active inclusion and social innovation, investing in children, housing, active ageing, social services of general interest); (2) social protection activities (poverty and social exclusion, health care, long-term care, pensions). It is also responsible for the European social fund (ESF), one of the European Structural and Investment Funds, specifically targeted to improving the employment opportunities and standard of living for workers in the internal market (Article 162 of the TFEU - Treaty on the Functioning of the European Union) and to strengthening the EU economic, social and territorial cohesion (Art. 174 TFEU). With Europe 2020, the activities of DG-EMPL have been significantly re-oriented towards increasing social inclusion, also through the provision of social services. Its two main tools are the 'European platform against poverty and social exclusion' and the 'Social investment package'.

The European platform is one of the seven flagship initiatives of the Europe 2020 strategy, designed to help EU countries reach the very ambitious headline target of lifting 20 million people out of poverty and social exclusion. It features five areas of action (EC, 2010b; 2015), two of which 
are directly relevant for social services: (a) delivering actions to fight poverty and exclusion across the policy spectrum, among which the 'Social protection and access to essential services' action explicitly addresses services, especially long-term care and active ageing, as well as social innovation; (b) making EU funding deliver on the social inclusion and social cohesion objectives of Europe 2020, among which the 'Developing an evidence-based approach to social innovations and reform' action also addresses social services. The European platform is also responsible for three coordination tools: (1) the 'European semester' for monitoring the structural reforms of member states; (2) the 'Scoreboard' for keeping track of the progress towards the poverty targets; (3) the 'Annual convention of the European platform against poverty and social exclusion' as an opportunity for dialogue between policy-makers and non-governmental stakeholders.

The Social investment package re-pledges the EC commitment to link social expenditure to the economic goals of growth, employment and productivity and it outlines the reforms necessary to secure more adequate and sustainable social policies (EC, 2014). The key policy recommendations include: (1) a 'simplification' of services in order to improve their efficiency; (2) institutional reforms and, in particular, 'deinstitutionalisation', i.e. a transition from institutional to community-based care; (3) the 'modernisation' of social policies (such as activation measures or personalised approaches); (4) innovation as an essential element of social investment.

$D G-R E G I O$ is responsible for implementing the so-called European Cohesion policy, established after the Single European Act of 1986 in order to strengthen the economic, social and territorial cohesion of the EU and reduce regional disparities within and between member states. Its programmes are financed mainly through the European regional development fund (ERDF) and the Cohesion fund (CF) (EC, 2013e, p. 3), albeit the European social fund (ESF) also contributes significantly and some resources can be pooled from the other two European investment and structural funds: the European agricultural fund for rural development (EAFRD) and the European maritime and fisheries fund (EMFF).

The EU Cohesion policy is implemented through multi-annual investment programmes, with management procedures shared among the EC, member states, and regional and local authorities. Since its onset in 1989, there have been five programming periods. The current one covers the years 2014-20, which coincide with the last seven years of the Europe 2020 strategy. In fact, this new round of the EU Cohesion policy introduces a very relevant social dimension: four of its 11 'thematic objectives' are dedicated to the 'inclusive growth' priority (see Table 2.1). Moreover, for the first time, a minimum of 23 per cent of the European social fund is earmarked for the implementation of Cohesion policy. 
Table 2.1 EU Cohesion policy 2014-20: priorities, thematic objectives and European structural and investment funds

\begin{tabular}{|c|c|c|c|c|c|c|c|c|c|c|c|}
\hline \multirow[b]{2}{*}{$\begin{array}{l}3 \text { Priorities } \\
11 \text { Thematic } \\
\text { objectives } \\
\\
5 \text { European } \\
\text { structural \& } \\
\text { investment funds }\end{array}$} & \multicolumn{4}{|c|}{ SMART } & \multicolumn{3}{|c|}{ SUSTAINABLE } & \multicolumn{4}{|c|}{ INCLUSIVE } \\
\hline & 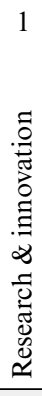 & 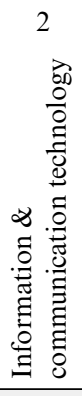 & 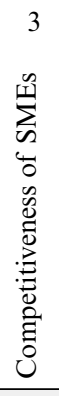 & 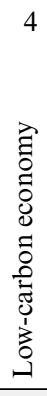 & 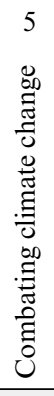 & 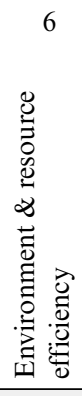 & 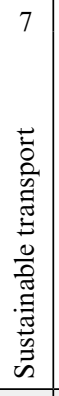 & 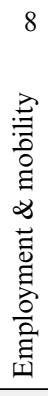 & 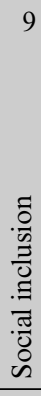 & 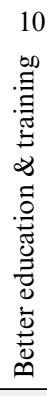 & 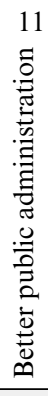 \\
\hline ESF & $\mathrm{x}$ & $\mathrm{x}$ & $\mathrm{x}$ & $\mathrm{x}$ & & & & $\mathrm{X}$ & $\mathrm{X}$ & $\mathrm{X}$ & $\mathrm{X}$ \\
\hline ERDF & $\mathrm{X}$ & $\mathrm{X}$ & $\mathrm{X}$ & $\mathrm{X}$ & $\mathrm{x}$ & $\mathrm{x}$ & $\mathrm{x}$ & $\mathrm{x}$ & $\mathrm{x}$ & $\mathrm{x}$ & $\mathrm{x}$ \\
\hline $\mathrm{CF}$ & & & & $\mathrm{X}$ & & & $\mathrm{X}$ & & & & $\mathrm{X}$ \\
\hline EAFRD & $\mathrm{x}$ & $\mathrm{x}$ & $\mathrm{x}$ & $\mathrm{x}$ & $\mathrm{x}$ & $\mathrm{x}$ & & $\mathrm{x}$ & $\mathrm{x}$ & $\mathrm{x}$ & \\
\hline EMFF & & & $\mathrm{X}$ & & & $\mathrm{X}$ & & $\mathrm{X}$ & & & \\
\hline
\end{tabular}

Source: Authors' compilation.

Of the four thematic objectives attached to the 'Inclusive growth' priority, the one on Social inclusion has direct relevance for social services. Its 'lines of action' include:

- enhancing access to affordable, sustainable and high-quality services, including health care and 'social services of general interest', also in rural areas (this line can draw upon resources from ESF, ERDF, EAFRD);

- investing in health care and social infrastructure (ERDF);

- promoting the transition from institutional to community-based services (ERDF);

- supporting social enterprises (ESF, ERDF).

This thematic objective also includes five 'areas of action' (see Figure 2.1), among which the most directly relevant for social services are, again, 'Social inclusion' and 'Transition from institutional to community-based care'. Within the first, the key policy recommendations mirror those of the Social Investment Package: simplification of services, public administration reforms to enhance access to affordable, sustainable and high-quality 


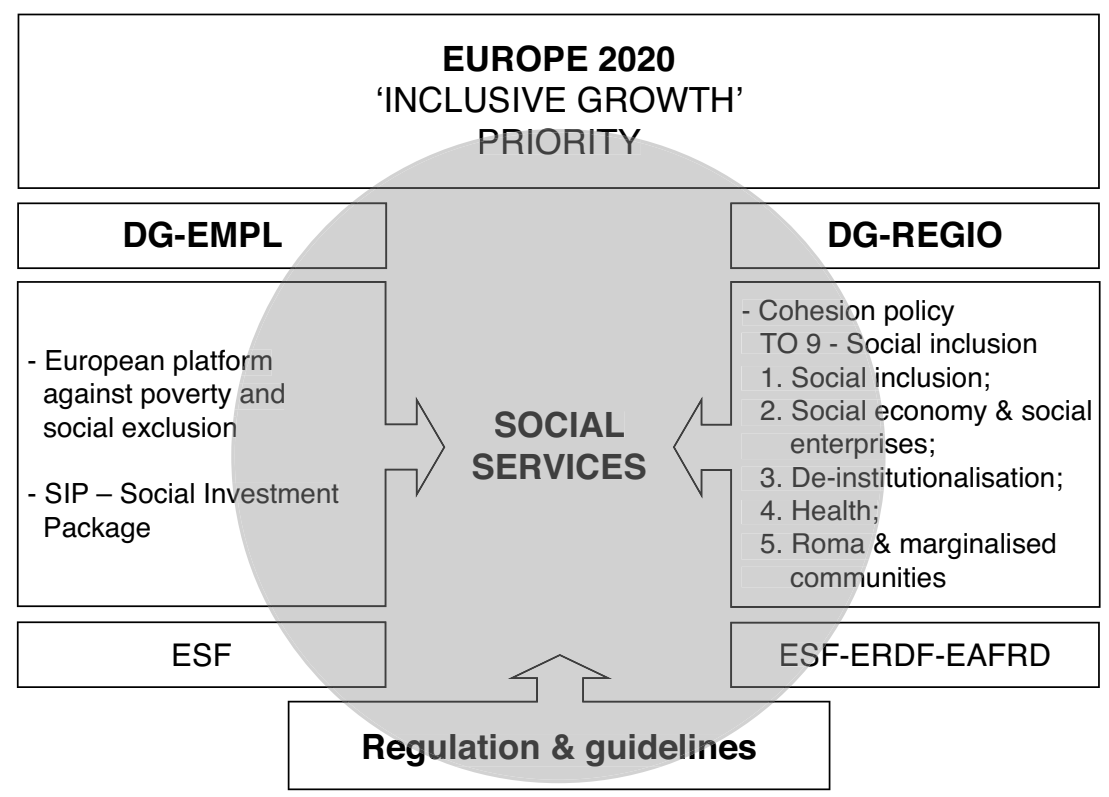

Source: Authors' compilation.

Figure 2.1 Current EU funds and tools concerning social services

services, modernising social services, innovation. In the second, initiatives aim at transferring resources, workforce and users (children, older people, people with disabilities) from institutional to community- and familybased care. In this area, strong emphasis is placed on the notion that EU financial support to deinstitutionalisation must be temporary, as new care systems must become self-sustained.

\section{A Complex, Redundant and Sometimes Unfriendly Policy Framework}

The EU social policy agenda has come a long way since the Lisbon council, in several respects. Despite the financial crisis, the notion of social investment has resisted and social inclusion has become an explicit priority of the Europe 2020 strategy, now integrated in the EU Cohesion policy. While the autonomy of member states in social policy has been preserved, it is now more firmly cast in a European framework, with 'soft' governance and coordination tools and some funding, through Cohesion policy. In particular, the open method of coordination is emphasised in many social policy areas. 
On the other hand, the current policy framework and tools - especially in what concerns social services - appear convoluted, redundant and often confusing. To make everything fit in and to integrate everything with everything else, a very complex policy architecture has been devised, based on a multitude of objectives, priorities, flagship initiatives, thematic objectives, guidelines, lines of action, areas of action, platforms, packages, and so on and so forth, which risks discouraging and disorienting, rather than accompanying and supporting the average stakeholder. Moreover, tensions remain - unsolved - between goals and resources: while the Europe 2020 social goals remain very ambitious, the resources mobilised (essentially the ESF and part of the ERDF) to support the less developed member states and regions are rather limited. In addition, while Cohesion policy provides resources for 'investment' in social infrastructure, the resources needed to 'operate' social services must come from member states, an option not always viable in times of austerity.

As will be argued later, the above described social policy framework is the result of a compromise between different approaches and interests, whereby very different goals, but also a number of enduring ambiguities and even contradictions - coexist. Among these, the tension between liberalising services as economic activities, on the one hand, and keeping the universal character of social services, on the other, will be the focus of the next section.

\section{THE REGULATION OF SOCIAL SERVICES OF GENERAL INTEREST (SSGI): STATE AID AND PUBLIC PROCUREMENT RULES}

\section{The Emergence and Ambiguity of the SSGI Concept Within Services of General Interest (SGI)}

The term 'Services of general economic interest' (SGEI) was first introduced in Article 86(2) of the 1957 Treaty of Rome. It was an entirely new concept that was not recognised in any language of the original member states or in the scientific literature (Bauby, 2011). However, it was not until the strategies of privatisation, liberalisation and integration into the single market gained momentum during the 1990s that the concept was actually developed (Gómez-Barroso and Marbán-Flores, 2013). At the time, it was broadly accepted that those strategies needed to be accompanied by programmes to foster social and political integration; therefore, accessible and affordable services of general interest (SGI) became an important part of these efforts (Clifton et al., 2005). 
As a consequence, the Commission dedicated a first Communication to the SGI (EC, 1996), wherein the SGEI were basically defined as a subset of SGI services: "market services which the member states subject to specific public service obligations by virtue of a general interest criterion' (EC, 1996, p. 2). No reference was made to social services. It was in the Green paper on $S G I$ (EC, 2003, p. 5) that it was recognised that 'the reality of services of general interest, which include services of both general economic and non-economic interest [. . .], covers a broad range of different types of activities, from certain activities in the large network industries to health, education and social services'. A year later, the White paper on SGI introduced the expression 'social services of general interest' (SSGI), stressing that they should 'have a specific role to play as an integral part of the European model of society' (EC, 2004, p. 16), albeit they remained under the responsibility of individual member states.

The message was reasserted in the European social agenda (EC, 2005b). Thus, 'to identify and recognise the specific characteristics of SSGI and to clarify the framework in which they operate' became a 'policy development initiative' for the Lisbon programme (EC, 2005a). The initiative took form with a first communication, in 2006, devoted to SSGI (EC, 2006). The White paper had already clarified that 'while there is some interest in further clarification of the situation of organisations providing social services under community law and in protecting the non-economic services of general interest as part of the European social model, there is broad agreement that the community should not be given additional powers in the area of non-economic services' (EC, 2004, p. 24). In the same way, the 2006 communication was limited to a finer definition of SSGI (health services were excluded from the list) and to clarify the conditions 'for the application of certain community rules' (EC, 2006, p. 6).

The Commission further refined its position on SSGI in 2007 (EC, 2007) and has since published three biennial reports (EC, 2008b; 2010c; 2013f). As the 2013 report acknowledges, the issue that 'has dominated the scene for at least the last decade' is the application of EU general rules on state aid, internal market and public procurement to social services. Indeed, accompanying the communication of 2007 , two 'Frequently asked questions (FAQ)' documents on the application of state aid and public procurement rules were published. Three years later, in December 2010, both FAQ documents were updated and combined as a Guide (EC, 2010d). Following the adoption of a communication that set out the Commission's approach to SGI in a comprehensive manner (EC, 2011), the Commission updated the Guide in February 2013 (EC, 2013g).

The documents issued by the Commission not only made the rules of application clear, but also justified why rules were needed and welcomed. 
The third biennial report stated that 'in recent years, several public authorities and civil society organisations representing service users and providers have claimed that the EU rules create unnecessary difficulties'. Rejecting such views, the Commission argued that EU rules took into account the specific characteristics of social services and that, 'if the public authorities apply them correctly, these rules can help them organise and finance highquality cost-effective social services in a transparent manner' (EC, 2013f, p.4).

\section{State Aid Rules}

The 2011 Almunia package consisted of four documents, setting out the conditions under which state aid in the form of public service compensation was compatible with the Treaty on the Functioning of the European Union (TFEU). The rules apply whenever public authorities in member states (be they national, regional or local) finance SGEI. They therefore apply to social services of an economic nature. The notion of 'economic nature' is a source of uncertainty. The criterion marking the economic character of the activity is not related to the status of the service provider, or to the nature of the service itself. Indeed, this is the first of a number of subsequent questions that should be answered to define a framework applicable to social services.

a) Do public services have an economic nature? Any activity consisting of offering goods and/or services in a given market is an economic activity as defined by the competition rules. The fact that the activity in question is termed 'social' or is carried out by a non-profit operator is not in itself sufficient to avoid classification as an economic activity. In spite of this general rule, certain activities of a purely social nature have been determined to be non-economic. Examples are the management of compulsory insurance schemes pursuing an exclusively social objective, functioning under the principle of solidarity, and offering insurance benefits independently of contributions, or the provision of public education financed by the public budget and carrying out a State task. Anyway, in many instances the application of this key notion can only rely on a case by case analysis and will remain a relative 'source of uncertainty' (Baquero Cruz, 2013, p. 309).

b) Is public funding always regarded as state aid? State funding for the provision of social services of an economic nature is not regarded as state aid, provided that four conditions - 'the Altmark criteria' are met: (1) the beneficiary of a state funding mechanism must be formally entrusted with the provision of an SGEI, the obligations 
of which must be clearly defined; (2) the parameters for calculating the compensation must be established beforehand in an objective and transparent manner; (3) the compensation cannot exceed what is necessary to cover all or part of the costs incurred in the discharge of the SGEI, taking into account a reasonable profit; (4) where the beneficiary is not chosen pursuant to a public procurement procedure, the compensation granted must be determined on the basis of an analysis of the costs that a typical 'well-run' undertaking would have incurred.

c) Is state aid compatible with the internal market? Public service compensation that constitutes state aid can yet be compatible with the internal market and the Commission does not need to be notified. Indeed, this is the general rule for social services. The 2011 Decision (EC, 2012c) exempts providers from prior notification, regardless of the level of financing, for all services 'meeting social needs as regards health and long-term care, childcare, access to and reintegration into the labour market, social housing and the care and social inclusion of vulnerable groups'. This list is exhaustive. However, the last sentence allows the flexibility to include various services for those groups in society 'that need them the most, in accordance with the variety of needs and preferences of users that may result from different geographical, social or cultural situations among the member states'.

Of course, compatibility does not mean absolute freedom. While public authorities do not have to notify the Commission of their financing of social services, they must nevertheless establish a clear and precise act of entrustment and ensure that the service provider does not receive any overcompensation.

\section{Public Procurement Rules}

On the other hand, in its Charter of fundamental rights (EC, 2012a, p. 18), the Commission also stated that 'all too often, public authorities assume that by complying with state aid rules they have ensured the legality of their financing arrangements'. When organising and financing social services, public authorities must not only identify the amount of finance, but also address other questions. Who will provide the service: the public authority itself or an external provider? If an external provider, how will it be selected? It is in this context that public procurement rules come into play.

In the end, social services are barely affected by the rules laid down in the directives in force, considering that 'given the importance of the cultural context and the sensitivity of these services, member states should be 
given wide discretion to organise the choice of the service providers in the way they consider most appropriate' (European Parliament and Council, 2014 , p. 7). Nevertheless, public authorities must always comply with the treaty principles of transparency, equal treatment and non-discrimination, mutual recognition and proportionality. In particular, this means that the authority in charge must: (1) adequately advertise its intention to outsource the provision of the social service and to conclude a public service contract with an external provider; and (2) deal in a non-discriminatory and impartial way with all the providers that have shown an interest in such a contract.

Thus, the EU public procurement rules apply only when a public authority decides to outsource the provision of a service to an external provider that the public authority pays to provide. They do not apply when the public authority grants licences or authorisations to all service providers that meet the conditions laid down for the provision of services beforehand.

\section{DISCOURSES AND IDEOLOGIES UNDERLYING THE CURRENT EU STRATEGIES FOR SOCIAL SERVICES}

The above-described redundancies and ambiguities in current policy tools and regulations concerning social services are paralleling ambiguities on the discursive level. EU discourses on social policy reflect the "changing interests of changing coalitions of actors in the general intergovernmental bargaining process ... [ [of which the] product represents a discursive settlement of conflict' (Barbier, 2011, p. 12; emphasis in original). While in the early 2000 s the EU was dominated by left-leaning governments, rightwing governments are now in the overwhelming majority (The Economist, 7 June 2011). This change, which is a result of both the entrance of new member states with a more conservative or neo-liberal orientation and political shifts in the old ones, has been reflected in the post-Lisbon casting of strategies for social services.

As discussed earlier, the Lisbon council established important new intergovernmental bargaining arenas, in particular with the introduction of the Open method of coordination tool in the field of social protection and the cross-European social benchmarking/target-setting. Arguably, the Lisbon strategy marked a policy shift in the EU position on social services (Daly, 2006). Such services were now assigned a central role in easing the post-industrial transformation that European countries faced. As stressed by Hantrais (2004, p. 193): 
At the heart of the 2000 social policy agenda was the modernisation of the European social model, which had the overall aim of strengthening the role of social protection as an effective tool for the management of change [...] Modernisation and improvement of social protection were central components in the response to the advent of the knowledge economy and to changing social and family structures.

While social services had previously been regarded merely as policies to alleviate negative externalities caused by market failures, the Lisbon strategy underscored the positive externalities. This new orientation manifested itself in the setting of targets related to alleviating critical social problems, and to the volume of specific social services to be provided by member countries. For example, the policy documents produced in the wake of the 2002 Barcelona council (extending the targets established in Lisbon from six to 20) linked the provision of childcare services to the achievement of a number of broader societal goals. These included fighting school drop-out, countering the intergenerational transmission of social inequalities, mobilising (female) labour, promoting gender equality and even strengthening European fertility (EC, 2013a, pp. 4-6).

Moreover, by setting ambitious targets for employment rates, with the intention 'to realise Europe's full employment potential' (EC, 2000, p. 15), the European Union took an important step towards endorsing a social model in which social services played an integral part. Prominent social scientists were commissioned to sketch the underlying rationale. They argued that to create good quality jobs and a suitable productive labour force to fill them, it was necessary to regard welfare state expenditure on social and educational services as 'investments' (Esping-Andersen et al., 2002). Furthermore, by placing employment promotion high on the agenda, a welfare model close to the Beveridge ideal was embraced, in contrast to a North American-style neo-liberal model (Korpi and Palme, 2003).

Thus, by speaking simultaneously to economic and social concerns, the social investment perspective epitomises Barbier's 'discursive settlement of conflict' (2011, p. 12) between neo-liberal and social democratic ideals inherent in the way the Lisbon strategy evolved throughout the 2000s. This decade saw the mobilisation of a series of parallel concepts such as 'flexicurity', 'social entrepreneurship' and 'social innovation' that shared this dual ideological orientation. Hence, this new vocabulary, and the sets of actions that such ideas prompted, took what Offe (2003, p.440) has characterised as a century-old 'European way' of handling conflict and diversity through institutionalisation, to a new level.

In the transition from the Lisbon strategy to the Europe 2020 and Social investment package strategies, while the conceptual framework has remained the same, it is now more specific in what concerns the method- 
ology to achieve the objectives (Budd, 2013, p. 287). The Package aims at 'redirecting member states' policies, where needed' (EC, 2013b, pp. 3-4), by linking the Europe 2020 targets with the relevant EU funds. As mentioned earlier, in the 2014-20 period, the Commission proposes to set aside at least 23 per cent of the European social fund for activities that align with the social investment perspective, while the European regional development fund should complement such social investment by funding social service infrastructure. In this way, by strengthening the dimension of 'aid conditionality' (Van Gerven et al., 2014), a change in the mode of governance is observed; the 'soft' law mechanisms of recommendations and policy learning are significantly hardened.

In particular, the Platform against poverty is meant to provide new impetus to the promotion of better social services. The Commission argues that among poverty's multiple dimensions there is 'inadequate access to basic services' (EC, 2010b, p.6) and calls for greater efficiency through service consolidation and better delivery, together with the mobilisation of a greater set of actors and instruments. A number of social services are emphasised as essential in alleviating poverty: childcare (the Commission mentions both 'quality childcare' and 'affordable childcare'), educational services, employment services, health services and care services for older people, and even publicly provided basic financial services (EC, 2010b, pp.4-5, 11). Partly overlapping with the mentioned services, a number of critical policy areas are highlighted, including education, social care, housing, health, reconciliation and family policies (EC, 2010a, p.5). Because people living in rural areas in Europe are disproportionally affected by poverty, the Commission also calls for an up-scaling of social service infrastructure in these areas (EC, 2010a, pp. 13-14). In this manner the Commission recognises the critical role of social services in achieving territorial cohesion, a perspective that social scientist have already pointed out (Kolberg and Esping-Andersen, 1991).

The social investment strategy put forward in the Platform outlines the reforms needed to secure more adequate and sustainable social policies by investing in people's skills and capabilities, by improving performance and devising more efficient and effective inclusion strategies and social budgets. As welfare systems face demographic change and financial crises, they need to modernise social policies and the way in which they are financed. Importantly, the Commission argues that providing welfare through services, rather than cash transfers, may be more conducive to the investment perspective (EC, 2013b, p. 10). This may be interpreted as an appreciation of the social democratic service-intensive welfare model. And yet the Commission's recommendations in other respects align more with what has been labelled the liberal welfare state model (Esping-Andersen, 1990). 
This alignment concerns the debate on 'targeting' versus 'universalism', which goes to the heart of the political economy of the welfare state. While acknowledging that 'both universalism and selectivity need to be used in an intelligent way' (EC, 2013b, p. 9), the Commission takes quite a strong stance in encouraging member states to better target the provision of cash benefits and social services, in order to increase efficiency and effectiveness (EC, 2013b, pp. 3, 5, 9). In favouring selectivity, the Commission approximates the neo-liberal-type model for allocating welfare (Esping-Andersen, 1990).

Also, when discussing non-public sources of welfare, the Commission touches upon ideological questions fundamental to the welfare state. When it recommends that private enterprises provide more social services to their employees and governments further rely on third-sector involvement in welfare production and delivery (EC, 2013b, pp.5-6) it endorses again a neo-liberal agenda rather than a social democratic one. The Commission also calls for more support to private businesses that promote social inclusion (the so-called 'social entrepreneurship'). Furthermore, it encourages member states to make use of financial arrangements whereby private investors are allowed to finance social programmes in return for the opportunity to receive some economic rewards (the so-called 'social impact bonds') (EC, 2013b, pp.18-19). It also points to 'activation' measures (that is, measures that entail some kind of formalised activity in which the benefit claimant participates) as a prime tool for transforming social expenditures into investments. Furthermore, it emphasises conditionality and temporary rather than permanent benefits (EC, 2013b, pp. 3, 8-9). At a first glance, activation, as a supply-side measure in the active labour market policy toolbox, resonated well with the social democratic ideology. Yet the implied extension of activation as a measure to deal with not only the unemployed but with all benefit and service claimants, and the emphasis on conditionality, brings the Commission's recommendations closer to neo-liberal positions, as do also the Commission's call for more 'incentives to work' (EC, 2013b, pp. 5, 10, 12).

Likely reflecting a 'discursive settlement of conflict' - that is, a necessary compromise meant to accommodate the different welfare models coexisting in Europe - some underlying dilemmas remain in the new strategy documents. This is observed in the call for more conditionality (EC, 2013b, pp. 3, 8-9) and monitoring (EC, 2013b, p.5) on the one hand, and a call for simplified procedures (EC, 2013b, pp. 3, 9) on the other. Indeed, imposing monitoring and conditionality necessitates a large legal and administrative apparatus that renders procedures quite complicated, to the extent that clients find themselves sanctioned for violating conditions of which they were not aware (Kvist and Harsløf, 2014). Likewise, the call 
for more individualised social services may be challenging to realise if it is to be implemented under a regime of more top-down control. Perhaps, as Peña-Casas (2011, p. 162) observes, emphasising individualisation more than anything ushers in a new and more individualised approach to social problems: social services will be provided with the purpose of ensuring that individuals can anticipate and manage change.

\section{CONCLUDING REMARKS}

The construction of the European Union is proving to be a long and complex journey. One of the many milestones along the way was reached at the turn of the new millennium, when it seemed that the conditions for a leap forward were in place. The Union seemed able to move forward both externally, by shifting its borders to the east, and internally, by building up a more cohesive entity.

However, the impetus soon lost momentum. It may be that there was no clear idea of how to orchestrate the implementation of the strategy, or the words did not represent real intentions. After only four years, in the midterm review of the Lisbon strategy it was already clear that the European project would basically keep travelling essentially on economic rails. To make matters worse for the progress of a social Europe, a financial crisis arose. The term 'crisis' is a reduction of the causes and consequences of the economic crash that began in 2007. The aftermath of the crisis had and continues to have a significant impact on the social well-being of millions of European citizens, as the response of European institutions has far more to do with macroeconomic orthodoxy than with taking care of social circumstances. Austerity is putting pressure on social services in the domestic context and the European Union puts indirect pressure, via fiscal policy and European Monetary Union criteria, especially on the most crisis-ridden countries.

This does not mean that the notion of a European social policy has been abandoned. Some of it has remained, and has even been perfected. The Europe 2020 strategy maintains social policy as a priority, and has integrated it with the growth and competitiveness goals of the EU social and territorial cohesion policy. Indeed, social services have a more prominent position in the current strategy. Moreover, a relevant part of the structural and investment funds to pursue social policy goals has been earmarked, marking a slight change in the mode of governance towards 'harder' law mechanisms.

Yet the actual shape of the European social policy model has two important problems. The first and main one concerns credibility and trust. The 
past 15 years have been a period of big words and small achievements. There is no reason to believe that the political momentum is now stronger. The second problem lies in organisation and planning. The social policy framework, tools and regulations - especially in what concerns social services - are extremely redundant and unnecessarily complex. As this chapter has tried to show, there are an ever-increasing number of objectives, priorities, initiatives, actions, tools and so on, that make the policy framework almost impenetrable in terms of understanding and access, let alone implementation, to the average stakeholder, whether public or private. Moreover, a tension remains between goals and resources. While the EU cohesion policy provides resources for social infrastructure 'investments', the resources needed to operate social services and inclusive measures must come from member states, thereby requiring a firm commitment from the latter to support an expansive - albeit reformed - system of social services. Unfortunately, this does not seem to be happening. Tensions also remain between considering social services as 'economic' activities - subject to competition principles - or considering them as 'social' activities, as the contradictory regulation shows.

It is clear that so much diversity, within and across the different areas of social services in Europe, makes it difficult to devise and apply common rules. However, the gap between strict common rules and procedural rules could accommodate an ample set of actions, such as the establishment of minimum thresholds or social coverage parameters, genuine and clear guidelines for the allocation of funds, or basic regulations to address the uncertainties that actors in the social services experience. In contrast, if the soft regulatory approach persists and most of the effort is left to member states, a multiple-speed social Europe might become a permanent feature. The analyses of strategies, tools and discourses in this chapter suggest that a neo-liberal ideology is still permeating the post-Lisbon social policy directions - even if some elements of the social democratic model have been reintegrated. Ultimately, prioritising the economic-financial Europe over the social-political Europe might mean that social inequalities will continue to exist and possibly grow.

\section{NOTE}

* This chapter is the joint product of a close collaboration among all three authors. However, the Introduction should be attributed to José Luis Gómez-Barroso and Ivan Harsløf, section 1 to Stefania Barillà, section 2 to José Luis Gómez-Barroso, and section 3 to Ivan Harsløf. The conclusions are obviously shared. 


\section{REFERENCES}

Agh, A. (2010), 'The Europe 2020 strategy: a new vision for the EU', in H. Butković and V. Samardžija (eds), From the Lisbon Strategy to Europe 2020, Institute for International Relations - IMO, Zagreb and 'EU i' in cooperation with the Delegation of the European Union to the Republic of Croatia, accessed at: www. zagreb.hr/euzg/eu_publikacije/From_the_lisbon_strategy_to_europe_2020.pdf.

Baquero Cruz, J. (2013), 'Social services of general interest and the State aid rules', in U. Neergaard, E. Szyszczak, J.W. van de Gronden and M. Krajewski (eds), Social Services of General Interest in the EU, The Hague: T.M.C. Asser PressSpringer, pp. 287-313.

Barbier, J.-C. (2011), Changes in Political Discourse from the Lisbon Strategy to Europe 2020: Tracing the Fate of 'Social Policy', Brussels: ETUI.

Bauby, P. (2011), 'From Rome to Lisbon: SGIs in primary law', in E. Szyszczak, J. Davies, M. Andenæs and T. Bekkedal (eds), Developments in Services of General Interest, The Hague: T.M.C. Asser Press-Springer, pp. 19-36.

Budd, L. (2013), 'Europe 2020: a strategy in search of a regional policy rationale?', Policy Studies, 34 (3), 274-90.

Butković, H. and V. Samardžija (2010), 'From the Lisbon Strategy to Europe 2020. An introduction', in H. Butković and V. Samardžija (eds), From the Lisbon Strategy to Europe 2020, Institute for International Relations - IMO, Zagreb and 'EU i' in cooperation with the Delegation of the European Union to the Republic of Croatia, accessed at: www.zagreb.hr/euzg/eu_publikacije/From_ the_lisbon_strategy_to_europe_2020.pdf.

Clifton, J., F. Comín and D. Díaz Fuentes (2005), 'Empowering Europe's citizens? Towards a charter for services of general interest', Public Management Review, 7 (3), 417-43.

Council of Europe (1961), European Social Charter, Turin, 18 October, CETS No. 035.

Daly, M. (2006), 'EU social policy after Lisbon', Journal of Common Market Studies, 44 (3), 461-81.

Decaro, M. (2011), 'La strategia di Lisbona 2000-2010', in M. Decaro (ed.), Dalla Strategia di Lisbona a Europa 2020. Fra governance e government dell'Unione europea, Collana Intangibili, Fondazione Adriano Olivetti, Roma, accessed at: www.fondazioneadrianolivetti.it/_images/pubblicazioni/collana/120111100032Str ategia $\% 20 \mathrm{di} \% 20$ Lisbona.pdf.

EC (1996), Services of General Interest in Europe, Brussels: Communication from the Commission, COM(96)443 final.

EC (2000), Social Policy Agenda, Brussels: Communication from the Commission to the Council, the European Parliament, the Economic and Social Committee and the Committee of the Regions, COM(2000)379 final.

EC (2003), Green Paper on Services of General Interest, Brussels: Communication from the Commission, $\operatorname{COM}(2003) 270$ final.

EC (2004), White Paper on Services of General Interest, Brussels: Communication from the Commission, $\operatorname{COM}(2004) 374$ final.

EC (2005a), Annex to the Communication from the Commission to the Council and the European Parliament - Common Actions for Growth and Employment: The Community Lisbon Programme, Brussels: Commission Staff Working Document, SEC(2005)981 final. 
EC (2005b), The Social Agenda, Brussels: Communication from the Commission, $\operatorname{COM}(2005) 33$ final.

EC (2006), Implementing the Community Lisbon Programme: Social Services of General Interest in the European Union, Brussels: Communication from the Commission, COM(2006)177 final.

EC (2007), Services of General Interest, including Social Services of General Interest: A New European Commitment, Brussels: Communication from the Commission, COM(2007)725 final.

EC (2008a), Renewed Social Agenda: Opportunities, Access and Solidarity in 21st Century Europe, Brussels: Communication from the Commission to the Council, the European Parliament, the Economic and Social Committee and the Committee of the Regions, COM(2008)412 final.

EC (2008b), Biennial Report on Social Services of General Interest, Brussels: Commission Staff Working Document, SEC(2008)2179 final.

EC (2010a), The European Platform against Poverty and Social Exclusion: a European Framework for Social and Territorial Cohesion, Brussels: Communication from the Commission to the European Parliament, the Council, the European Economic and Social Committee and the Committee of the Regions, COM(2010)758 final.

EC (2010b), List of Key Initiatives. Accompanying Document to the Communication from the Commission to the European Parliament, the Council, the European Economic and Social Committee and the Committee of the Regions. The European Platform Against Poverty and Social Exclusion: A European Framework for Social and Territorial Cohesion COM(2010) 758 final, Brussels: Commission Staff Working Paper, SEC(2010)1564 final.

EC (2010c), Second Biennial Report on Social Services of General Interest, Brussels: Commission Staff Working Document, SEC(2010)1284 final.

EC (2010d), Guide to the Application of the European Union Rules on State Aid, Public Procurement and the Internal Market to Services of General Economic Interest, and in Particular to Social Services of General Interest, Brussels: Commission Staff Working Document, SEC(2010)1545 final.

EC (2011), A Quality Framework for Services of General Interest in Europe, Brussels: Communication from the Commission, COM(2011)900 final.

EC (2012a), Charter of Fundamental Rights of the European Union, Official Journal of the European Union, 26 October 2012 (2012/C 326/02).

EC (2012b), Consolidated Version of the Treaty on the Functioning of the European Union, Official Journal of the European Union, 26 October 2012 (2012/C $326 / 47)$.

EC (2012c), Commission Decision, of 20 December 2011, on the Application of Article 106(2) of the Treaty on the Functioning of the European Union to State Aid in the Form of Public Service Compensation Granted to Certain Undertakings Entrusted with the Operation of Services of General Economic Interest, Official Journal L7, 11.01.2012.

EC (2013a), Barcelona Objectives: The Development of Childcare Facilities for Young Children in Europe with a View to Sustainable and Inclusive Growth, Luxembourg: Publications Office of the European Union.

EC (2013b), Towards Social Investment for Growth and Cohesion, including Implementing the European Social Fund 2014-2020, Brussels: Communication from the Commission to the European Parliament, the Council, the European Economic and Social Committee and the Committee of the Regions, $\operatorname{COM}(2013) 83$ final. 
EC (2013c), Strengthening the Social Dimension of the Economic and Monetary Union, Brussels: Communication from the Commission to the European Parliament and the Council, COM(2013)690 final.

EC (2013d), 'Annual Activity Report - Employment, Social Affairs and Inclusion', accessed at: ec.europa.eu/atwork/synthesis/aar/doc/empl_aar_2013.pdf.

EC (2013e), 'Annual Activity Report - DG Regional and Urban Policy', accessed at: ec.europa.eu/atwork/synthesis/aar/doc/regio_aar_2013.pdf.

EC (2013f), Third Biennial Report on Social Services of General Interest, Brussels: Commission Staff Working Document, SWD(2013)40 final.

EC (2013g), Guide to the Application of the European Union Rules on State Aid, Public Procurement and the Internal Market to Services of General Economic Interest, and in Particular to Social Services of General Interest, Brussels: Commission Staff Working Document, SWD(2013)53 final.

EC (2014), 'Europe 2020: a Strategy for European Union Growth', accessed at: eurlex.europa.eu/legal-content/EN/TXT/HTML/?uri=URISERV:em0028\&from $=\mathrm{CS}$.

EC (2015), 'European Platform against Poverty and Social Exclusion', accessed at: ec.europa.eu/social/main.jsp?catId=961.

Esping-Andersen, G. (1990), The Three Worlds of Welfare Capitalism, Cambridge: Polity Press.

Esping-Andersen, G., D. Gallie, A. Hemerijck and J. Myles (eds) (2002), Why We Need a New Welfare State, Oxford: Oxford University Press.

European Parliament and Council (2014), Directive 2014/24/EU of 26 February 2014 on public procurement and repealing Directive 2004/18/EC, Official Journal L 94, 28.3.2014.

Gómez-Barroso, J.L. and R. Marbán-Flores (2013), 'Basic financial services: a new service of general economic interest?', Journal of European Social Policy, 23 (3), 314-21.

Hantrais, L. (2004), Family Policy Matters: Responding to Family Change in Europe, Bristol: Policy Press.

Hemerijck, A. (2012), 'Two or three waves of welfare state transformation?', in N. Morel, B. Palier and J. Palme (eds), Towards a Social Investment Welfare State? Ideas, Policies and Challenges, Bristol: Policy Press.

Kolberg, J.-E. and G. Esping-Andersen (1991), 'Welfare states and employment regimes', in J.-E. Kolberg (ed.), The Welfare State as Employer, New York: M.E. Sharpe.

Korpi, W. and J. Palme (2003), 'New politics and class politics in the context of austerity and globalization: welfare state regress in 18 countries, 1975-95', American Political Science Review, 97 (3), 425-46.

Kvist, J. and I. Harsløf (2014), 'Workfare with welfare revisited: instigating dual tracks for insiders and outsiders', in I. Lødemel and A. Moreira (eds), Activation or Workfare? Governance and the Neo-liberal Convergence, Oxford: Oxford University Press.

Lundvall, B.-A. and E. Lorenz (2012), 'From the Lisbon Strategy to Europe 2020', in N. Morel, B. Palier and J. Palme (eds), Towards a Social Investment Welfare State? Ideas, Policies and Challenges, Bristol: Policy Press.

Offe, C. (2003), "The European model of "social" capitalism: can it survive European integration?' The Journal of Political Philosophy, 11 (4), 437-69.

Peña-Casas, R. (2011), 'Europe 2020 and the fight against poverty and social 
exclusion: fooled into marriage?', in D. Natali and B. Vanhercke (eds), Social Developments in the European Union 2011, Brussels: ETUI, pp. 159-85.

The Economist (2011), 'Left out: fewer and fewer European countries are run by left-leaning governments', The Economist, 7 June.

Van Gerven, M., B. Vantercke and S. Gürocak (2014), 'Policy learning, aid conditionality or domestic politics? The Europeanization of Dutch and Spanish activation policies through the European Social Fund', Journal of European Public Policy, 21 (4), 509-27. 